\title{
VIENNA RADIUM INSTITUTE RADIOCARBON DATES II
}

\section{HEINZ FELBER}

Institut für Radiumforschung und Kernphysik der Österr,

Akademie der Wissenschaften, Vienna, Austria

Measurements have continued with the same proportional counter system, the same procedure in sample pretreatment, methane preparation and measurement, and the same age calculation using a half-life of $5568 \pm 30 \mathrm{yr}$ as described previously (R., 1970, v. 12, p. 298-318).

Uncertainties quoted are single standard deviations originating from the statistical nature of radioactive decay including standard, sample, background, and half-life. No $\mathrm{C}^{13} / \mathrm{C}^{12}$ ratios were measured.

The following list presents most samples of our work in the last year. Sample descriptions have been prepared in cooperation with submitters.

\section{ACKNOWLEDGMENTS}

I have again to express many thanks to I. L. Stein for the excellent work in sample preparation and to E. Pak for the careful work in operation of the dating equipment.

\section{SAMPLE DESCRIPTIONS}

I. GEOLOGY, GEOGRAPHY, SOIL SCIENCE, AND FORESTRY

\section{Austria}

\section{VRI-170. Grossenzersdorf, N.ö.}

Oak wood, taken from depth 10 to $12 \mathrm{~m}$ below surface $(154 \mathrm{~m}$ sea level) near Grossenzersdorf $\left(48^{\circ} 12^{\prime} \mathrm{N}\right.$ Lat, $16^{\circ} 36^{\prime} \mathrm{E}$ Long), Lower Austria. Coll. 1969 and subm. by H. Bednar, Inst. f. Holzforschung, Hochschule f. Bodenkultur, Vienna. Comment (H.B.): dating necessary for biologic and technical analysis of wood.

\section{VRI-175. Rutzendorf, N.ö.}

$7000 \pm 160$

Wood from layer of main stems of trees ca. $8 \mathrm{~m}$ below surface in gravel of river platform "Prater Terrasse" (Danube), Rutzendorf $\left(48^{\circ}\right.$ $12^{\prime} 16^{\prime \prime} \mathrm{N}$ Lat, $16^{\circ} 36^{\prime} 38^{\prime \prime} \mathrm{E}$ Long), Lower Austria, E of Vienna. Coll. 1969 and subm. by J. Fink, Geog. Inst., Univ. of Vienna. Comment (J.F.): for a long time the Prater Terrasse has been considered of late Pleistocene age (Fink and Majdan, 1954). Similar wood findings near Linz by $\mathrm{H}$. Kohl and in the Tullner Feld by L. Piffl, suggest a Holocene age. This sample proves suggestion. However, some parts of Prater Terrasse are surely of Pleistocene age (Fink, 1955).

\section{Lugendorfer Au series, N. $\ddot{\mathbb{C}}$.}

Peat and wood taken from different depths of bog, Lugendorfer $\mathrm{Au}$ (48 $30^{\prime} \mathrm{N}$ Lat, $15^{\circ} 12^{\prime} \mathrm{E}$ Long), ca. $15 \mathrm{~km}$ S of Zwettl, Lower Austria. Coll. 1967 and subm. by F. Kral, Inst. f. Waldbau, Hochschule f. Boden- 
kultur, Vienna. Absolute dating of pollen-analyzed horizons in peat profile was undertaken to clarify questions on forest history.

\section{VRI-180. Depth 31 to $39 \mathrm{~cm}$}

$1860 \pm 80$

Brown wood-peat (usual sort of peat in bogs of Low Austrian landscape "Waldviertel") from depth 31 to $39 \mathrm{~cm}$. Comment (F.K.): pollen diagram gives evidence that sample covers the change from naturally grown Pinus-Abies-Fagus-forest to man-influenced forest rich in Pinus. Small pieces of charcoal point to rooting out by burning. Evidently human influence did not begin before 12th century (Foundation of Stift Zwettl 1137). Date not in contradiction because sample is composed of peat of different age: blackish-brown wood-peat lying below $35 \mathrm{~cm}$ is essentially older than date, brown Sphagnum-wood-peat overlying $35 \mathrm{~cm}$ grew after rooting out and is relatively young. In sample both components are mixed in equal parts by volume, but material of higher age overbalances because of its much slower growth rate.

\section{VRI-181. Depth 70 to $80 \mathrm{~cm}$}

$5130 \pm 100$

Decayed wood (Alnus and Quercus) from depth 70 to $80 \mathrm{~cm}$. Comment (F.K.): pollen-analytic placement of sample (in Sub-boreal) is uncertain for several reasons. Hence, date is not necessarily in contradiction. In this horizon scattered pollen grains of Larix are observed, suggesting that Larix grew locally even in the Neolithic. Up to now Larix in this area was thought not to be of natural origin, but artificially brought in.

VRI-182. Dachstein, O.̈̈.

Recent

Partially decayed wood (Pinus cembra?) in 23 to $25 \mathrm{~cm}$ depth of a 55-cm-thick raw humus layer. "Zirmgrube" on plateau of Mt. Dachstein, ca. $6 \mathrm{~km} \mathrm{~S}$ of Hallstatt $\left(47^{\circ} 31^{\prime} \mathrm{N}\right.$ Lat, $13^{\circ} 39^{\prime} \mathrm{E}$ Long), Upper Austria. Coll. 1969 and subm. by F. Kral. Comment (F.K.): raw humus formation began in 1500 B.C., Sub-boreal, and stopped in 17th century A.D. as was indicated by pollenanalytic dating. This method puts horizon of depth 23 to $25 \mathrm{~cm}$ into the last centuries B.c. Date suggests that much later a branch may have fallen into relatively loose deposit.

\section{Wallsee-Mitterkirchen series, o.ö.}

Wood from depths 6-to-7-m-thick pebble horizon lying on slateclay and covered by alluvial sand. Samples dredged during work on Danube water-power sta. in Wallsee-Mitterkirchen area $\left(48^{\circ} 10^{\prime} \mathrm{N}\right.$ Lat, $14^{\circ} 43^{\prime}$ E Long), Upper Austria. Coll. 1966 and subm. by F. Makovec, österr. Donaukraftwerke AG., Ybbs a.d.Donau.

\section{VRI-85. Wallsee I}

$$
310 \pm 80
$$

Wood from wood bearing layer in ballast horizon, $3 \mathrm{~m}$ above slateclay. Comment (F.M.): date agrees with supposed connection between wood-bearing layer and high level of Danube R. at end of 16th century. 
VRI-86. Wallsee II

Stem-wood from pebble horizon, taken near slate-clay zone. Comment (F.M.): date supports supposition that pebble horizon was formed in last $2000 \mathrm{yr}$.

VRI-87. Wallsee III

$6560 \pm 140$

4610 в.c.

Stem-wood from pebble horizon, lying on slate-clay boundary. Comment (F.M.): sample transposed; does not date alluvial detritus deposition.

\section{Ödenwinkelkees series, Salzburg}

Peat and wood taken at moraine ridge of ödenwinkelkees (Slupet-

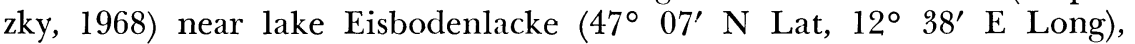
$2060 \mathrm{~m}$ alt., Stubachtal, Hohe Tauern, Salzburg. Coll. by H. Slupetzky and G. Patzelt; subm. by H. Slupetzky, Geog. Inst., Univ. of Salzburg. Approx. date of glacier advance is expected.

\section{VRI-154. Ödenwinkelkees 1}

$6690 \pm 110$

Wood sample from peat bed taken at terminus of moraine ridge. Coll. 1967.

\section{VRI-155. Ödenwinkelkees 2}

$5580 \pm 100$

Peat sample from pressed peat bed. Coll. 1968.

3630 B.c.

\section{VRI-150. Imst, Tirol}

$1450 \pm 70$

Charcoal from burning horizon below weathering zone of B-horizon in colluvial calcareous brown earth over loamy-sandy slope material. Over burning horizon there lay $30 \mathrm{~cm}$ of B-horizon and $5 \mathrm{~cm}$ of humus

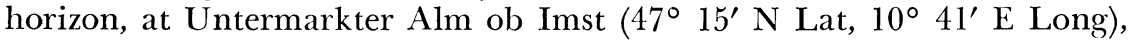
Tyrol, $1500 \mathrm{~m}$ alt. Coll. 1968 and subm. by I. Neuwinger, Forstliche Bundesversuchsanstalt, Bodenkundliches Lab., Imst. Comment (I.N.): displacement of horizons by slope sliding is possible. Date fixes burning horizon chronologically.

\section{VRI-151. Untergurgl-Poschach, Tirol}

$3640 \pm 150$

Charcoal from burning horizon over eroded iron-podsol, ca. $30 \mathrm{~cm}$ below surface, partially carried away or buried by torrents carrying stones and earth. Pinus cembra forest above Untergurgl-Poschach $\left(48^{\circ} 53^{\prime} \mathrm{N}\right.$ Lat, $11^{\circ} 02^{\prime} \mathrm{E}$ Long), Ötztal, Tyrol, in area of the bioclimatic sta. of Forstliche Bundesversuchsanstalt Obergurgl (Neuwinger, Czell, 1959) at $2050 \mathrm{~m}$ alt. Coll. 1968 and subm. by I. Neuwinger. Comment (I.N.): displacement of horizons by sliding is possible. Date gives terminus ante quem for soil genesis. 
VRI-160. Obergurgl, Tirol

Charcoal pieces mixed with sand, humus, and rootlet remnants, from burning horizon 15 to $25 \mathrm{~cm}$ below recent humus horizon of an iron-podsol over an eroded older podsol. Austrian Alps of ötztal, surroundings of Obergurgl $\left(46^{\circ} 52^{\prime} \mathrm{N}\right.$ Lat, $11^{\circ} 02^{\prime} \mathrm{E}$ Long), on road to the Timmelsjoch, alt. $2040 \mathrm{~m}$. Coll. 1965 by M. Doenecke; subm. by I. Neuwinger. A special pretreatment was used (similar to that of Haynes, 1966), to remove plant contaminants. Comment (I.N.): date gives terminus ante quem for soil genesis.

\section{Rotmoos series, Tirol}

Cyperaceae-peat samples from bog Rotmoos, from different depths. Rotmoostal (46 $50^{\circ} 30^{\prime \prime} \mathrm{N}$ Lat, $11^{\circ} 01^{\prime} 30^{\prime \prime} \mathrm{E}$ Long), $2260 \mathrm{~m}$ alt, Obergurgl, Tyrol. Coll. 1969 and subm. by S. Bortenschlager, Inst. f. Bot. Systematik und Geobot., Univ. of Innsbruck.

\section{VRI-156. Rotmoos I}

$5170 \pm 100$ 3220 B.c.

Depth 243 to $244 \mathrm{~cm}$. Comment (S.B.): indicates beginning of organic sedimentation.

\section{VRI-157. Rotmoos II}

$4680 \pm 100$

Depth 223 to $226 \mathrm{~cm}$. Comment (S.B.): 1st peat layer being thicker, it could coincide with major glacier retreat.

\section{VRI-158. Rotmoos III}

$4340 \pm 90$

Comment (S.B.): thick peat layer with remains of wood between clay layers, perhaps proving main glacier fluctuation.

\section{Roppen north series, Tirol}

Pieces of charcoal from burning horizon in forest $\mathrm{S}$ of Roppen (47 $17^{\circ} \mathrm{N}$ Lat, $10^{\circ} 49^{\prime} \mathrm{E}$ Long), near Imst, Tyrol, coll. near new forest road, $900 \mathrm{~m}$ alt. Subm. by H. Heuberger, Geog. Inst., Univ. of Innsbruck. General Comment: burning horizon of brown earth buried under landslide moraine of Mt. Tschirgant (Heuberger, 1968). Brown earth was formed on silicic moraine. Landslide moraine, predominantly dolomitic limestones, is ca. $4 \mathrm{~m}$ thick at this location. At site landslide moraine was cut by dredger.

\section{VRI-144. Roppen north 1}

$3230 \pm 90$ which could not be removed chemically because material was not perfectly charred and much of it would have been lost. With assumed admixture of $5 \%$ recent material, charcoal age is 3440 B.P.

VRI-190. Roppen north 2

Coll. 1969 by I. Neuwinger. Sample free of recent contaminants. 
VRI-176. Roppen, Tirol

Charcoal mixed with sand, humus and rootlet remnants from burning horizon below 20-cm-thick colluvial A-horizon, taken near new forest road, $900 \mathrm{~m}$ alt., ca. $200 \mathrm{~m}$ from moraine of Mt. Tschirgant landslide. Forest S of Roppen ( $47^{\circ} 13^{\prime} \mathrm{N}$ Lat, $10^{\circ} 49^{\prime} \mathrm{E}$ Long), near Imst, gorge of Oetz Valley, Tyrol. Coll. 1969 and subm. by I. Neuwinger. Comment (I.N.): dating is to aid interpretation of the complex soil profile.

\section{Baumkirchen-Fritzens series, Tirol}

Samples from clay-pit Baumkirchen-Fritzens $\left(47^{\circ} 18^{\prime} 25^{\prime \prime} \mathrm{N}\right.$ Lat, $11^{\circ} 34^{\prime} 19^{\prime \prime}$ E Long), Tyrol.

General Comment (F.F.): banded silt and clay is doubtless primary sedimentation. VRI-161 dates 1st fossils found in a $30 \mathrm{yr}$ search; up to now, banded silt was thought to be sterile. Dates were surprising because until now this lacustrine sediment was thought to be either Riss Würm Interglacial or Early Würm (Fliri et al., 1970).

\section{VRI-161. Baumkirchen 1}

$26,800 \pm 1300$

Small sample of conifer needles and fragments of branch from Pinus mugo found at $681 \mathrm{~m}$ alt. in perpendicular wall, at NNW part of excavation, $10 \mathrm{~m}$ below surface. Location of sampling was below horizontal layer of banded silt, $6.5 \mathrm{~m}$ thick, in completely undisturbed position. Sample discovered 1969 by O. Melander; coll. by F. Fliri and W. Resch; subm. by F. Fliri, Geog. Inst., Univ. of Innsbruck. Comment (F.F.): sample was prepared from $100=\mathrm{dm}^{3}$ block of clay with many tracks of aquatic animals and calcareous pebbles. Very little pollen was detected (S. Bortenschlager: Pinus, Gramineae, Cyperaceae).

\section{VRI-173. Baumkirchen 2}

$28,900 \pm 700$ 26,950 B.C.

Wood (Hippophae rhamnoides), at $660 \mathrm{~m}$ alt. in perpendicular wall at S part of excavation. Location of sample was below layer of nearly horizontal banded silt, $30 \mathrm{~m}$ thick, in completely undisturbed position. Coll. 1969 and subm. by F. Fliri. Comment (F.F.): intensive search for organic material brought this sample only 5 mos. after VRI161. In same horizon again were found many tracks of fishes and a fist-sized calcareous pebble. Date consistent with VRI-161.

\section{Schlatenkees series, Venediger Group, Osttirol}

Peat and wood from different depths of peat profile of bog, 135 $\mathrm{cm}$ thick, present-day above timber line. Schlatenkees $\left(47^{\circ} 06^{\prime} 53^{\prime \prime} \mathrm{N}\right.$ Lat, $12^{\circ} 26^{\prime} 46^{\prime \prime}$ E Long), outside of right lateral moraine, SW of Salzbodensee, $2165 \mathrm{~m}$ alt., Venediger Group, Hohe Tauern, East-Tyrol. Coll. 1969 and subm. by G. Patzelt, Meteorolog. Inst., Univ. of Innsbruck. 
General Comment (G.P.): pollen analysis proves repeated changes in vegetation. The horizons pointing to climate deterioration and advances of glacier Schlatenkees are chronologically fixed by dating. Wood samples throughout were clearly older than peat samples, as inferred from stratigraphic interpolation; similar observations have been made on other peat profiles: Wood horizons are always found immediately above peat layers pollen analysis of which points to clearly deteriorated climatic conditions for tree growth. Interpretation is that trees do not fall into bog immediately after dying, but are transported from up-valley after being killed by the advancing glacier.

VRI-138. Depth $25 \mathrm{~cm}$

Peat.

\section{VRI-134. Depth 33 to $35 \mathrm{~cm}$}

Wood from uppermost, youngest, wood horizon of peat profile, pointing to climatic deterioration; belongs to glacier maximum.

\section{VRI-139. Depth $45 \mathrm{~cm}$}

Peat.

\section{VRI-135. Depth 65 to $67 \mathrm{~cm}$}

Wood from 2nd wood horizon overgrown by wood-free peat; belongs to glacier maximum.

\section{VRI-172. Depth $80 \mathrm{~cm}$}

Peat.

VRI-177. Depth $105 \mathrm{~cm}$

Peat.

\section{VRI-137. Depth $135 \mathrm{~cm}$}

Wood. Comment (G.P.): sample taken from base of bog gives minimum age of underlying moraine.

\section{Rostocker Huitte series, Venediger Group, Osttirol}

Peat from different depths of a bog near refuge Rostocker Hütte (47 03' 19" N Lat, $12^{\circ} 18^{\prime} 07^{\prime \prime} \mathrm{E}$ Long), $2200 \mathrm{~m}$ alt., Venediger Group, East-Tyrol. Coll. 1969 and subm. by G. Patzelt.

\section{VRI-178. Depth $35 \mathrm{~cm}$}

$425 \pm 60$

Sample from peat layer between loamy deposits. Comment (G.P.): sample dates loamy deposits above and below peat layer, washed in by brook draining Simonykees Glacier at the time of its maximum extension. 
VRI-179. Depth $170 \mathrm{~cm}$

Comment (G.P.): pollen analysis reveals change of vegetation pointing to deterioration of climatic conditions which is chronologically fixed by dating.

\section{ARCHAEOLOGIC SAMPLES}

\section{A. Austria}

\section{VRI-164. Klosterneuburg, N.ö.}

One of several wooden posts arranged in a double row, $70 \mathrm{~cm}$ below ground in loess, obviously, to save a water-ditch. Klosterneuburg ( $47^{\circ} 21^{\prime}$ N Lat, $16^{\circ} 18^{\prime} \mathrm{E}$ Long), boundary towards Kierling, field "Eisenhütte." Coll. 1969 by J. W. Neugebauer; subm. by R. Pittioni, Inst. f. Ur- und Frühgeschichte, Univ. of Vienna. Comment (R.P.): exact interpretation impossible because no systematic excavation exists.

\section{Pottenbrunn series, N.ö.}

Wood, remnants of coffin from grave field in tertiary ballast. Ballastpit Haas, Pottenbrunn (48 $14^{\prime} \mathrm{N}$ Lat, $\left.15^{\circ} 42^{\prime} \mathrm{E} \mathrm{Long}\right)$, Lower Austria. Coll. 1964 by H. Friesinger; subm. by R. Pittioni.

General Comment (R.P.): archaeologic chronology fixes grave field at change of 9 th to 10th century A.D.

\section{VRI-117. Grave 29}

$$
1150 \pm 70
$$

$120 \mathrm{~cm}$ below surface. Comment (R.P.): after correction for de Vries-effect (Suess, 1965), date gives useful completion of archaeologic chronology.

VRI-118. Grave 40

$$
1400 \pm 70
$$

\section{A.D. 550}

$140 \mathrm{~cm}$ below surface. Comment (R.P.): even after correction for de Vries-effect (Suess, 1965) date too old by 300 to $400 \mathrm{yr}$.

\section{VRI-116. Trasdorf, N.ö.}

$$
2160 \pm 80
$$

210 B.C.

Charcoal from ground plan of late Hallstattian settlement object found in loam pit of brickyard in Trasdorf $\left(48^{\circ} 19^{\prime} \mathrm{N}\right.$ Lat, $15^{\circ} 53^{\prime} \mathrm{E}$ Long), Lower Austria. Coll. 1965 by A. Persy; subm. by R. Pittioni. Comment (R.P.): present date agrees with earlier date, VRI-60 (Felber, $1968 ; 1970)$ with result $2240 \pm 90$. Date younger than expected by archaeologic evidence.

VRI-149. Hallein, Slzbg. $<\mathbf{2 0 0}$

Wood (Picea) remnants of fire sticks in so-called "Heidengebirge," former salt mine pits filled with loam, clay, and different salts. Salt mine Dürrnberg, Hallein $\left(47^{\circ} 41^{\prime} \mathrm{N}\right.$ Lat, $13^{\circ} 05^{\prime} \mathrm{E}$ Long), Salzburg. Coll. 1967 by O. Schauberger; subm. by F. Morton, Prähist. Sta., Hallstatt, O.ö. Comment (F.M.): fire sticks could belong to Hallstatt period 
or to Middle age. According to estimated age limit, after correction for de Vries-effect (Suess, 1965), sample belongs to time after A.D. 1650.

\section{Dormitz series, Tirol}

Charcoal from an "Aufschüttungslinse" (fill up lens) in "Ackerterrassen" (soil rising in terraces) at Dormitz $\left(47^{\circ} 20^{\prime} \mathrm{N}\right.$ Lat, $10^{\circ} 50^{\prime} \mathrm{E}$ Long), Tyrol. Coll. 1968 and subm. by S. Bortenschlager, Inst. Bot. Systematik und Geobot., Univ. of Innsbruck.

\section{VRI-142. Dormitz I}

Charcoal uniformly dispersed in lens from 25 to $65 \mathrm{~cm}$ depth. Comment (S.B.): sample dates Ackerterrassen, frequently found in Tyrol and in Alpine foreland. Pollen analysis and conclusions of historians suggest post-Roman origin but before A.D. 800. All previous speculations from natural origin to origination by Illyrians are discarded.

\section{VRI-143. Dormitz II}

$$
2230 \pm 70
$$

Charcoal from base of lens, $70 \mathrm{~cm}$ below surface. Comment (S.B.): sample was taken from a stone ring, presumably from a fireplace. It is questionable whether sample is related to lens or not. If it is, sample should have the same age as VRI-142, and human origin of Ackerterrassen would be proved. Result verifies human origin.

\section{Brigantium-Bregenz series, Vorarlberg}

Samples from stables of Roman camp Brigantium, excavated below Josef-Huter-Street 12, Cut II, SW profile, Bregenz $\left(47^{\circ} 30^{\prime} \mathrm{N}\right.$ Lat, $9^{\circ}$ 43' E Long), Vorarlberg. Coll. 1967 by E. Vonbank; subm. by R. Pittioni. General Comment (E.V.): dates in excellent agreement with ceramic dating and stratigraphy.

VRI-113. Bregenz 1

$$
2000 \pm 80
$$

50 B.c.

Horse dung, taken from undermost dark layer, depth $2.40 \mathrm{~m}$.

VRI-114. Bregenz 2

Unknown organic material, depth $2.40 \mathrm{~m}$.

70 B.C.

VRI-115. Bregenz 3

$$
1870 \pm 80
$$

A.D. 80

Wood from intact bottom boards of stables. Depth $1.70 \mathrm{~m}$ below Roman road.

$$
\text { B. Italy }
$$

\section{VRI-136. Lago di Ledro, Italy}

$$
1080 \pm 70
$$

Wood from pile from Lake Ledro (45 $51^{\prime} 37^{\prime \prime} \mathrm{N}$ Lat, $10^{\circ} 45^{\prime} 56^{\prime \prime}$ E Long) $7 \mathrm{~km}$ SE of Riva del Garda, prov. Trento, Italy, $655 \mathrm{~m}$ alt. Pile was lifted when power sta. was built. Coll. 1950 by Mus. Civico, 
Riva; subm. by F. Morton. Comment (F.M.): part of pile dwelling (Battaglia, 1953; Morton, 1967). Main part of findings from Lake Ledro belongs to Neolithic. Some Bronze age artifacts are also found. Therefore, pile dwellings reach into Bronze age. Date incomprehensible in this connection. A similar date was established from another sample by Univ. of Rome: Lago di Ledro B, R-339, $950 \pm 50$ (R., 1968, v. 10, p. 357). Older samples were also dated, Pi-88: $3137 \pm 105$ (R., 1961, v. 3 , p. 102), R-7: $3310 \pm 210$ (R., 1964, v. 6, p. 82).

\section{REFERENCES}

Alessio, M. and Bella, F., 1964, University of Rome carbon-14 dates II: Radiocarbon, v. 6 , p. 82 .

Alessio, M., Bella, F., Cortesi, C. and Graziadei, B., 1968, University of Rome carbon-14 dates VI: Radiocarbon, v. 10, p. 357.

Battaglia, R., 1953, La palafitta del Lago di Ledro nel Trentino: Mus. Storia nat. Venezia Tridentina Mem., v. 7, p. 3-63.

Felber, Heinz, 1968, Altersbestimmungen nach der Radiokohlenstoffmethode am Institut für Radiumforschung und Kernphysik IV: Sitzungsber. d. Österr. Akad. d. Wiss., v. 177, p. 113. p. 312 .

Ferrara, G., Fornaca-Rinaldi, G. and Tongiorgio, E., 1961, Carbon-14 dating in Pisa II: Radiocarbon v. 3, p. 102 .

Fink, J., 1955, Abschnitt Wien-Marchfeld-March: Geol. Bundesanstalt Verh., Wien, Sonderheft D, p. 82-115.

Fink, J. and Majdan, H., 1954, Zur Gliederung der pleistozänen Terrassen des Wiener Raumes: Geol. Bundesanstalt Jahrb., Wien, v. 97, no. 2, p. 211-249.

Fliri, F. et al., 1970, Der Bänderton von Baumkirchen-eine neue Schlüsselstelle des Eiszeitalters in den Alpen: Zeitschr. Gletscherkunde und Glazialgeol., Innsbruck, in press.

Haynes, C. V., Jr., 1966, Radiocarbon samples: chemical removal of plant contaminants: Science, v. 151, p. 1391.

Heuberger, H., 1968, Die Ötztalmündung: Festschrift H. Kinzl. Alpenländische Studien 1, Univ. of Innsbruck.

Morton, F., 1967, Der Pfahlbau im Ledrosee: Zeitschr. Vorgeschichte, Überlingen.

Neuwinger, I. and Czell, A., 1959, Standortuntersuchungen in subalpinen Aufforstungsgebieten: Forstwiss. Centralblatt 78. Jahrg., no. 11/12.

Slupetzky, H., 1968, Glaziologische und glaziomorphologische Untersuchungen im Stubachtal (Hohe Tauern): dissert., Wien.

Suess, H. E., 1965, Secular variations of the cosmic-ray-produced carbon-14 in the atmosphere and their interpretations: Jour. Geophys. Research, v. 70, p. 5937-5952. 